\title{
PENGARUH MODEL PEMBELAJARAN BERBASIS MASALAH TERHADAP HASIL BELAJAR MATEMATIKA DITINJAU DARI KEMAMPUAN BERPIKIR KRITIS SISWA KELAS IV SEKOLAH DASAR DI GUGUS I KECAMATAN BULELENG
}

\author{
K. Lestari ${ }^{1}$, N.Dantes ${ }^{2}$, Sariyasa ${ }^{3}$ \\ Program Studi Pendidikan Dasar, Program Pascasarjana \\ Universitas Pendidikan Ganesha \\ Singaraja, Indonesia
}
e-mail: (seni.lestari@yahoo.com,nyoman.dantes@pasca.undiksha.ac.id, sariyasa@pasca.undikhsa.ac.id)

\begin{abstract}
Abstrak
Penelitian ini bertujuan untuk mendeskripsikan pengaruh model pembelajaran berbasis masalah terhadap hasil belajar matematika ditinjau dari kemampuan berpikir kritis siswa kelas IV SD Di Gugus I Kecamatan Buleleng. Penelitian ini merupakan penelitian eksperimen semu. Dengan rancangan factorial design (rancangan faktorial) $2 \times 2$ dan desain penelitian post-test only control group design. Populasi penelitian ini adalah seluruh siswa Kelas IV SD Di Gugus I Kecamatan Buleleng yang terdiri dari 210 orang yang terdiri dari 4 kelas. Sampel yang ditentukan dengan teknik group random sampling. Data kemampuan berpikir kritis dikumpulkan dengan tes kemampuan berpikir kritis dan hasil belajar matematika ranah kognitif menggunakan tes pilihan ganda. Data dianalisis dengan menggunakan analisis Anava dua jalan berbantuan SPSS 17.00 for windows. Hasil Penelitian menunjukkan bahwa: Pertama, terdapat perbedaan hasil belajar matematika antara siswa yang mengikuti model pembelajaran berbasis masalah dengan siswa yang mengikuti model pembelajaran konvensional. Kedua, terdapat pengaruh interaksi antara model pembelajaran berbasis masalah dengan kemampuan berpikir kritis terhadap hasil belajar matematika. Ketiga, pada siswa yang memiliki kemampuan berpikir kritis tinggi, ada perbedaan hasil belajar matematika antara siswa yang mengikuti model pembelajaran berbasis masalah dengan siswa yang mengikuti model pembelajaran konvensional. Kempat, pada siswa yang memiliki kemampuan berpikir kritis rendah, ada perbedaan hasil belajar matematika antara siswa yang mengikuti model pembelajaran berbasis masalah dengan siswa yang mengikuti model pembelajaran konvensional.
\end{abstract}

Kata kunci:hasil belajar matematika, kemampuan berpikir kritis, pembelajaran berbasis masalah

\begin{abstract}
This study aims to determine the magnitude of the effect of problem-based learning models on mathematics learning outcomes in terms of critical thinking skills of fourth grade students in Elementary School, Buleleng District. This type of research is quasiexperimental research. The design used in this study is a $2 \times 2$ factorial design and posttest only control group design research design. The population of this study was all students of Grade IV Elementary School in Cluster I of Buleleng Subdistrict consisting of 210 people. A total of 92 students were selected as samples determined by group random sampling technique. Data on critical thinking skills were collected by tests of critical thinking skills and mathematics learning outcomes using multiple choice tests. Data were analyzed using analysis of two-way Anava assisted SPSS 17.00 for windows. Research results show that: First, there are differences in mathematics learning
\end{abstract}


outcomes between students who follow a problem-based learning model with students who follow conventional learning models. Second, there is the influence of the interaction between the problem-based learning model and the ability to think critically on the learning outcomes of mathematics. Third, in students who have high critical thinking skills, there are differences in mathematics learning outcomes between students who follow the problem-based learning model and students who follow conventional learning models. Fourth, in students who have low critical thinking skills, there are differences in mathematics learning outcomes between students who follow a problem-based learning model and students who follow conventional learning models.

Keywords: mathematics learning outcomes, critical thinking skills, problem based learning

\section{PENDAHULUAN}

Kemajuan suatu bangsa ditentukan oleh sumber daya manusianya. Sumber daya manusia ditentukan oleh pendidikan. Berhasil tidaknya pendidikan ditentukan salah satunya dari tenaga pendidiknya, antara lain guru yang kompeten, yang menguasai IPTEK dalam era globalisasi ini. Banyak hal yang kita alami dan kita nikmati dari hasil pendidikan. Tanpa adanya pendidikan kita tidak mengalami kemajuan seperti sekarang ini. Dalam proses pendidikan dilakukan usaha yang disengaja serta secara sadar, seperti yang tercantum dalam undang-undang no. 20 tahun 2003 yaitu: Pendidikan adalah usaha sadar dan terencana untuk mewujudkan suasana belajar dan proses pembelajaran agar siswa secara aktif mengembangkan potensi dirinya untuk memiliki kekuatan spiritual keagamaan, pengendalian diri, kepribadian, kecerdasan, akhlak mulia, serta keterampilan yang diperlukan dirinya, masyarakat, bangsa dan Negara. Jadi, dalam pendidikan mengandung tujuan yang ingin dicapai. Untuk mencapai tujuan pendidikan perlu melakukan usaha yang disengaja dan terencana dalam memilih materi (isi), strategi kegiatan dan teknik penilaian yang sesuai. Matematika merupakan ilmu universal yang mendasari perkembangan teknologi modern dan memiliki peranan yang sangat penting dalam berbagai disiplin serta memajukan daya pikir manusia. Pembelajaran matematika di sekolah memiliki empat tujuan utama yaitu: (I) melatih cara berpikir dan bernalar dalam menarik kesimpulan, (2) mengembangkan aktivitas kreatif yang melibatkan imajinasi, intuisi dan penemuan dengan mengembangkan pemikiran divergen, orisinil, rasa ingin tahu, prediksi, dan dugaan serta mencoba-coba, (3) mengembangkan kemampuan pemecahan masalah, dan (4) mengembangkan menyampaikan informasi atau mengkomunikasikan gagasan (Depdiknas, 2006).

Dari tujuan di atas terlihat bahwa matematika berfungsi sebagai alat untuk memecahkan masalah yang berkaitan nyata dengan kehidupan sehari-hari. Untuk mencapai tujuan pembelajaran mata pelajaran matematika tersebut, seorang guru hendaknya dapat menciptakan kondisi dan situasi pembelajaran yang memungkinkan siswa aktif membentuk, menemukan, dan mengembangkan pengetahuannya. Proses pembelajaran matematika perlu mendapat perhatian dan penanganan yang serius. Hal ini penting, sebab hasilhasil penelitian masih menunjukkan bahwa proses pembelajaran matematika di sekolah dasar masih belum menunjukkan hasil yang memuaskan. Hal ini dapat dilihat dari hasil ujian akhir sekolah (UN dan UASBN) dimana ratarata hasil belajar matematika untuk siswa sekolah dasar berkisar antara nilai 5 dan 6 , bahkan lebih kecil dari angka ini. Ini juga merupakan indikator yang menunjukkan bahwa kemampuan pemahaman siswa 
terhadap mata pelajaran matematika masih rendah.

Berdasarkan wawancara yang didapat saat diadakannya pertemuan dengan para guru di Gugus 1 Kecamatan Buleleng, guru mengeluhkan sebagian besar siswanya masih mendapat nilai sebagian besar kurang pada mata pelajaran matematika. Dalam pengajaran matematika umumnya para guru cendrung menerapkan metode pengajaran secara tradisional atau ekspositori. Karakteristik pembelajaran di sekolah dasar yang masih konvensional dan pelaksanaannya didominasi oleh guru memnyebabkan proses pembelajaran kurang melibatkan siswa sehingga siswa kurang terampil dan kemampuan berpikir kritis rendah dilihat dari rancangan dan penilaian pengajaran tradisional tersebut. Selain itu, rendahnya kemampuan berpikir kritis siswa di sekolah dasar juga di ketahui dari hasil penelitian yang dilakukan oleh Wijayanti (2015) yang menyatakan bahwa, kemampuan berpikir kritis siswa kelas IV di Gugus I ditunjukkan dengan rata-rata skor kemampuan berpikir kritis siswa sebesar 17,95 tergolong rendah dan persentase skor total kemampuan berpikir kritis siswa sebesar 30,61 \% tergolong sangat rendah. Indikator kemampuan berpikir kritis dengan persetase skor terkecil di SD ini adalah kemampuan melakukan induksi sebesar 13\%. Kemampuan berpikir kritis siswa kelas IV SD No. 1 Banyuning ditunjukkan dengan ratarata skor kemampuan berpikir kritis siswa sebesar 17 tergolong rendah dan persentase skor total kemampuan berpikir kritis siswa sebesar 28,54\% tergolong sangat rendah. Indikator kemampuan berpikir kritis dengan persetase skor terkecil di SD ini adalah kemampuan melakukan induksi sebesar $7 \%$. Kemampuan berpikir kritis siswa kelas $\mathrm{V}$ SD No. 8 Banyuning ditunjukkan dengan rata-rata skor kemampuan berpikir kritis siswa sebesar 9,46 tergolong sangat rendah dan persentase skor total kemampuan berpikir kritis siswa sebesar
$17,31 \%$ tergolong sangat rendah. Indikator kemampuan berpikir kritis dengan persetase skor terkecil di SD ini adalah kemampuan melakukan induksi sebesar $10 \%$. Hasil penelitian tersebut merupakan sebuah kanyataan bahwa kemampuan berpikir kritis siswa di sekolah dasar belum dikembangkan secara optimal.

Lebih lanjut Wijayanti (2015) menyatakan bahwa terjadi kaitan yang erat antara kemampuan berpikir kritis siswa dengan hasil belajar. Siswa yang memiliki kemampuan berpikir kritis yang baik akan menunjukkan bahwa dia sangat memahami suatu materi pelajaran dengan baik dan mengingatnya pula dengan baik. Hal tersebut akan berpengaruh terhadap peningkatan hasil belajar siswa. Kondisi yang ada pada saat ini justru terjadi sebaliknya, pengemasan pembelajaran matematika terutama matematika untuk kemampuan berpikir kritis dan hasil belajar matematika belum ditangani secara sistematis. Seperti halnya yang terjadi pada siswa kelas IV SD di gugus I Kecamatan Buleleng, hasil belajar siswa mata pelajaran matematika belum maksimal. Berdasarkan hasil dari studi dokumentasi yang dilaksanakan menunjukkan rata-rata nilai siswa kelas IV Gugus I Kecamatan Buleleng yang memiliki hasil belajar matematika belum mencapai rata-rata KKM.

Berdasarkan hasil observasi awal, ditemukan rata-rata nilai UAS siswa secara keseluruhan berada pada kategori sedang (65-79). Hal ini menunjukkan bahwa sebagian besar hasil belajar Matematika siswa belum maksimal. Berbagai faktor dapat mempengaruhi rendahnya hasil belajar siswa seperti strategi, metode, model, motivasi, intelegensi, pola asuh orang tua, minat belajar anak dan sebagainya. Khususnya di Gugus I Kecamatan Buleleng, faktor pertama penyebab rendahnya hasil belajar Matematika siswa adalah siswa sulit mengembangkan pemahaman dalam belajar. Berdasarkan hasil wawancara yang dilakukan, siswa menyatakan bahwa 
belum benar-benar paham dengan apa yang sebenarnya mereka pelajari. Terbukti dengan siswa tidak mampu mengaitkan apa yang mereka pelajari di kelas dengan kegunaannya dalam kehidupan sehari-harinya. Meraka hanya duduk dalam kelas lalu mendengarkan penjelasan guru tanpa memahami apa maksud dan tujuan pembelajaran yang sedang dilakukan. Anak-anak hanya menerima begitu saja konsep-konsep, memasukan angka-angka dan membuat tugas-tugas yang diberikan. Ketika anakanak mulai diberikan berbagai macam tugas, mereka akan mulai merasa terbebani, bosan, dan kehilangan rasa ingin menyelesaikan tugas yang diberikan. Hal tersebut akan menimbulkan rasa tak acuh dan tak peka siswa terhadap tugas yang diberikan.

Selain itu, berdasarkan hasil wawancara yang dilakukan dengan guru kelas IV SD Gugus I Kecamatan Buleleng, guru mengalami kesulitan menggembangkan rencana pembelajaran. Guru tidak banyak mengenal dan menggunakan model-model pembelajaran yang inovatif. Guru sebagai pengajar berperan amat penting mempengaruhi hasil belajar siswa. Peran guru, terutama bagi anak usia sekolah dasar tidak dapat digantikan oleh seperangkat komputer, televisi, radio ataupun perangkat lainnya. Guru seharusnya mampu berperan sebagai fasilitator dalam proses pembelajaran, tetapi hanya mengandalkan metode ceramah. Guru cenderung berperan sebatas hanya sebagai informator, pemberi informasi pada siswa. Penuangan informasi dari guru kepada siswa menyebabkan siswa lebih bersifat pasif, sehingga siswa lebih banyak menunggu sajian guru daripada mencari dan menemukan sendiri pengetahuan, keterampilan, atau sikap yang mereka butuhkan. Proses mental dan emosional yang seharusnya terjadi dalam pembelajaran pada kenyataannya belum terjadi secara optimal, karena proses belajar siswa belum dilakukan dengan berbagai macam cara dan kegiatan yang memungkinkan terjadinya interaksi antara individu-individu dan individu dengan lingkungannya. Akhirnya, anak-anak mulai kehilangan rasa ingin tahu dan belajar karena keterpaksaan.

Mengatasi persoalan di atas, maka perlu adanya inovasi dalam proses pembelajaran. Salah satu inovasi tersebut adalah guru mampu menggunakan model pembelajaran yang inovatif. Model pembelajaran inovatif diyakini mampu memfasilitasi siswa untuk mengembangkan kemampuan berpikir dan hasil belajar siswa. "Pembelajaran inovasi lebih menyediakan proses yang mengarah pada penemuan hakikat siswa sesuai fitrahnya sebagai manusia berpotensi" (Tukiran, 2014:55). Salah satu alternatif untuk memecahkan permasalahan di atas adalah dapat diterapkan model pembelajaran berbasis masalah. Model pembelajaran berbasis masalah (PBM) yang menekankan pada aktivitas siswa dalam menemukan sebuah konsep. Model PBM dapat dirancang penggunaannya oleh guru menurut kemampuan mereka dan menurut tingkat perkembangan intelektual siswanya. Model PBM merupakan pembelajaran yang membantu siswa menyusun pengetahuan mereka sendiri, berdasarkan masalah yang mereka peroleh dari pengalaman. Apabila siswa melakukan dan menemukan sendiri pemecahan masalah yang dihadapi sendiri melalui sebuah percobaan ataupun pengalamanpengalaman mereka, maka pembelajaran akan menjadi lebih bermakna bagi siswa. Bermaknya sebuah pembelajaran tentu akan meningkatkan pemahaman siswa terhadap materi yang dipelajari, sehingga hasil belajar siswa pun akan dapat ditingkatkan. Berdasarkan kajian permasalahan yang diuraikan dalam latar belakang permasalahan tersebut, kualitas pembelajaran matematika di sekolah dasar perlu ditingkatkan, terutama dalam penggunaan model pembelajaran agar lebih bervariasi dan siswa lebih terlibat 
aktif. Penerapan model pembelajaran berbasis masalah diprediksi dapat meningkatkan peran aktif siswa, sehingga dapat meningkatkan hasil belajar matematika dan kemampuan berpikir kritis siswa. Tujuan dari penelitian ini adalah untuk mengetahui pengaruh model pembelajaran berbasis masalah terhadap hasil belajar matematika ditinjau dari kemampuan berpikir kritis siswa kelas IV Sekolah Dasar Di Gugus I Kecamatan Buleleng.

\section{METODE PENELITIAN}

Penelitian ini merupakan penelitian eksperimen. Oleh karena tidak semua variabel (gejala yang muncul) dan kondisi eksperimen dapat diatur dan dikontrol secara ketat, maka penelitian ini dikategorikan penelitian eksperimen semu (quasi eksperimen), dengan rancangan penelitian two faktor design (desain faktorial $2 \times 2$ ). Penelitian ini melibatkan dua variabel model pembelajaran, yaitu model pembelajaran berbasis masalah dan model pembelajaran konvensional. Pada masing-masing perlakuan model tersebut,diselidiki pula interaksinya dengan kemampuan berpikir kritis. Kemampuan berpikir kritis matematika terdiri dari dua dimensi, yaitu kemampuan berpikir kritis tinggi dan kemampuan berpikir kritis rendah.

Populasi penelitian ini adalah semua siswa kelas IV Sekolah Dasar Di Gugus I Kecamatan Buleleng yang berjumlah 210 siswa. Sebelum pengambilan sampel dilaksanakan, terlebih dahulu dilakukan penguji kesetaraan kelas berdasarkan nilai ulangan akhir semester I pada siswa kelas IV. Untuk mengetahui kesetaraan kelas dalam penelitian ini dilakukan dengan uji anava satu jalur. Langkahlangkah yang ditempuh dalam pengambilan sampel penelitian ini yaitu melakukan uji kesetaraan terhadap seluruh kelas. Uji kesetaraan menggunakan ANAVA satu jalan dengan dibantu menggunakan program
SPSS 16.00 for windows, dengan signifikansi $5 \%$.

Kemudian dari anggota subjek penelitian yang berada pada setiap kelompok tersebut tidak semuanya diambil sebagai sampel, tetapi hanyalah diambil kelompok atas dan kelompok bawah dan telah dianggap bisa mewakili dari keseluruhan siswa pada kelompoknya yang memenuhi kriteria berdasarkan hasil tes kemampuan berpikir kritis.

Berikutnya, dalam rangka menentukan kelompok tinggi dan rendah berdasarkan tes kemampuan berpikir kritis tersebut di atas mengikuti anjuran dari Guilford (dalam Wilantara, 2003), sehingga dalam menentukan kelompok seperti yang telah dijelaskan bahwa perengkingan yang dilakukan terhadap kelompok tinggi dan kelompok rendah berdasarkan skor yang diperoleh dengan ketentuan bahwa; sebanyak $33 \%$ sebagai kelompok bawah, dan $33 \%$ dari kelompok tertinggi. Jumlah dari keseluruhan tersebut kemudian dijadikan sebagai subjek penelitian.

Oleh karena penelitian ini menggunakan 2 (dua) kelas sebagai kelas eksperimen dan 2 (dua) kelas sebagai kelas kontrol, dan masing-masing kelas dengan jumlah tidak sama, tetapi masingmasing kelas antara kelas eksperimen dan kelas kontrol mempunyai jumlah yang sama yaitu masing-masing sejumlah 70 dan 69 orang. Bedasarkan anjuran Guilford seperti tersebut diatas untuk masing-masing kelompok, antara kelompok yang mempunyai kemampuan numerik tinggi dan kemampuan numerik rendah masing-masing sebanyak 23 orang, berdasarkan penentuan kelompok atas dan kelompok bawah yang dihitung sebesar $33 \%$ dari masing masing kelompok (eksperimen maupun kontrol).

Variabel-variabel eksperimen dalam penelitian ini berupa variabel bebas (variabel independen), variabel terikat (variabel dependen) dan variabel moderator. Variabel bebas (Independent Variable) adalah variabel yang 
mempengaruhi atau yang menjadi sebab perubahan variabel terikat. Adapun variabel bebas dalam penelitian ini adalah model pembelajaran pembelajaran berbasis masalah. Variabel model pembelajaran memiliki dua dimensi, yaitu model pembelajaran berbasis masalah dan model pembelajaran konvensional. Variabel terikat (Dependent Variable) adalah faktor yang diobservasi dan diukur untuk menentukan pengaruh variabel bebas. Variabel terikat dalam penelitian ini adalah hasil belajar matematika. Varibel moderator adalah variabel yang mempengaruhi (memperkuat atau memperlemah) hubungan antara variabel bebas dengan variabel terikat. Varibel moderator dalam penelitian ini adalah Kemampuan berpikir kritis Matematika. Kemampuan berpikir kritis matematika ini memiliki dua dimensi yaitu kemampuan berpikir kritis tinggi dan kemampuan berpikir kritis rendah.

Data yang dikumpulkan dalam penelitian ini adalah data hasil belajar matematika siswa dan data kemampuan berpikir kritis. Sebelum instrumen ini digunakan maka dilakukan uji validitas isi dan reliabilitas. Untuk menentukan validitas isi (content validity) dilakukan oleh judges. Instrumen yang telah dinilai oleh judges selanjutnya diuji cobakan di lapangan. Tujuan dari pengujicobaan intrumen adalah untuk menentukan validitas dan reliabilitas instrumen, tingkat kesukaran dan daya beda pada instrumen kemampuan berpikir kritis dan hasil belajar matematika.

Dalam penelitian ini digunakan dua metode analisis yaitu analisis statistic deskriftif dan analisis varian (ANAVA) dua jalur. Teknik analisis deskriptif yaitu statistik yang digunakan untuk menggambarkan atau menganalisis suatu statistik hasil penelitian tetapi tidak digunakan untuk generalisasi/inferensi. Teknik analisis ini digunakan untuk mengetahui tinggi rendahnya kualitas dari hasil belajar matematika siswa. Analisis deskriptif yang digunakan adalah mean, median, modus, dan standar deviasi. Untuk menentukan tinggi rendahnya kualitas hasil belajar matematika, skor rata-rata (mean) tiap-tiap variabel dikonversikan dengan menggunakan kriteria rata-rata ideal (Xi) dan standar deviasi ideal (SDi). Sebelum melakukan analisis data, maka data yang diperoleh diuji asumsinya terlebih dahulu yaitu uji normalitas dan homogenitas varians.

Uji hipotesis dalam penelitian ini menggunakan Analisis Varian (ANAVA) dua jalur. Maka dari itu, dilakukan uji prasyarat karena ANAVA dua jalur merupakan salah satu bentuk analisis statistik parametrik. Candiasa (2010:220) mengungkapkan sebelum analisis statistik parametrik dilakukan, perlu adanya pemenuhan beberapa asumsi antara lain data berdistribusi normal dan memiliki sebaran data yang homogen. Sehingga, uji prasyarat yang dilakukan terdiri dari uji normalitas sebaran data dan uji homogenitas varian.

Analisis statistik yang digunakan untuk menguji hipotesis penelitian pertama dan kedua adalah ANAVA dua jalur. Jika hipotesis kedua signifikan atau $\mathrm{H}_{0}$ ditolak, yang artinya terdapat interaksi antara model pembelajaran berbasis masalah dengan kemampuan berpikir kritis dalam pengaruhnya terhadap hasil belajar matematika siswa, maka akan dilakukan uji untuk hipotesis 3 dan 4 yang akan dilakukan dengan uji Tukey $(Q)$.

\section{HASIL PENELITIAN DAN PEMBAHASAN}

Objek penelitian dalam penelitian ini adalah perbedaan hasil belajar matematika ditinjau dari kemampuan berpikir kritis. Rancangan penelitian yang digunakan adalah rancangan penelitian two faktor design (desain faktorial 2x2) dengan analisis ANAVA dua jalur. Perhitungan ukuran senteral (mean, modus, median) dan ukuran penyebaran data dapat dilihat pada Tabel 01 berikut. 
Tabel 01 Rekapitulasi Hasil Perhitungan Skor Hasil Belajar Matematika

\begin{tabular}{|l|r|r|r|r|r|r|r|r|}
\hline Statistik & \multicolumn{1}{|c|}{ A1 } & \multicolumn{1}{c|}{ A2 } & B1 & B2 & A1B1 & A1B2 & A2B1 & A2B2 \\
\hline N & 46 & 46 & 46 & 46 & 23 & 23 & 23 & 23 \\
\hline Rerata & 23,04 & 20,83 & 22,48 & 21,39 & 25,96 & 20,13 & 19 & 22,65 \\
\hline Median & 23 & 20 & 22 & 21,50 & 27 & 20 & 20 & 23 \\
\hline Modus & 22 & 20 & 20 & 20 & 30 & 18 & 20 & 20 \\
\hline Std. Deviasi & 4,69 & 3,60 & 4,89 & 3,59 & 3,77 & 3,61 & 3.07 & 3,19 \\
\hline Besaran & 21,99 & 12,99 & 23,94 & 12,95 & 14,22 & 13,03 & 9,45 & 10,15 \\
\hline Rentangan & 17 & 16 & 18 & 15 & 13 & 13 & 12 & 11 \\
\hline Skor Min & 13 & 12 & 12 & 13 & 17 & 13 & 12 & 17 \\
\hline Skor Max & 30 & 28 & 30 & 28 & 30 & 26 & 24 & 28 \\
\hline Total & 1060 & 958 & 1034 & 984 & 597 & 463 & 437 & 521 \\
\hline
\end{tabular}

Keterangan:

A1 = Kelompok siswa yang diajar dengan model pembelajaran berbasis masalah

A2 = Kelompok siswa yang diajar dengan model pembelajaran konvensional

B1 = Kelompok siswa yang mempunyai kemampuan berpikir kritis tinggi

B2 = Kelompok siswa yang mempunyai kemampuan berpikir kritis rendah

A1B1 = Kelompok siswa yang diajar dengan model pembelajaran berbasis masalah dan mempunyai kemampuan berpikir kritis tinggi.

A1B2 = Kelompok siswa yang diajar dengan model pembelajaran berbasis masalah dan mempunyai kemampuan berpikir kritis rendah

A2B1 = Kelompok siswa yang diajar dengan model pembelajaran konvensional dan mempunyai kemampuan berpikir kritis tinggi.

A2B2 = Kelompok siswa yang diajar dengan model pembelajaran konvensional dan mempunyai kemampuan berpikir kritis rendah.

Berdasarkan hasil pengujian

hipotesis yang telah diuraikan, terlihat bahwa keempat hipotesis yang diajukan pada penelitian ini telah berhasil menolak hipotesis nol, rincian hasil hipotesis tersebut sebagai berikut.

1. Perbedaan Hasil Belajar Matematika antara Siswa yang Mengikuti Model Pembelajaran Berbasis Masalah dengan Siswa yang Mengikuti Model Pembelajaran Konvensional pada Siswa Kelas IV SD Gugus I Kecamatan Buleleng

Berdasarkan hasil analisis data telah terbukti bahwa terdapat perbedaan hasil belajar matematika antara siswa yang mengikuti model pembelajaran berbasis masalah dengan siswa yang mengikuti model pembelajaran konvensional pada siswa kelas IV SD Gugus I Kecamatan Buleleng. Siswa yang mengikuti model pembelajaran berbasis masalah lebih baik dibandingkan dengan siswa yang mengikuti model pembelajaran konvensional. Hal ini ditunjukkan dengan rata-rata hasil belajar siswa yang mengikuti pembelajaran dengan model pembelajaran berbasis masalah dengan skor rata-rata 23,04 lebih tinggi daripada hasil belajar siswa yang mengikuti pembelajaran dengan model pembelajaran konvensional dengan skor rata-rata 20,83. Jadi dalam perbandingan antara model pembelajaran berbasis masalah dengan model pembelajaran konvensional, terdapat pengaruh model pembelajaran terhadap hasil belajar siswa. Dengan kata lain, ada perbedaan antara model pembelajaran berbasis masalah dan model pembelajaran konvensional dalam pembelajaran matematika. Dalam pembelajaran matematika, model pembelajaran berbasis masalah secara keseluruhan terbukti lebih baik dan efektif 
dibandingkan dengan model pembelajaran konvensional.

Pembelajaran yang bermakna dapat dilakukan dengan memberikan pembelajaran yang mengembangkan kemampuan berpikir siswa dalam memecahkan masalah yang berkaitan dengan kehidupan sehari-hari. Salah satu model pembelajaran yang mampu mengembangkan kemampuan berpikir siswa adalah model pembelajaran berbasis masalah. Model pembelajaran berbasis masalah merupakan pembelajaran yang penyampaiannya dilakukan dengan cara menyajikan suatu permasalahan yang kontekstual yang ditemukan oleh siswa dalam kehidupan sehari-hari. Siswa diorganisasikan untuk belajar dengan membentuk kelompok kecil dalam proses pembelajaran dengan menggunakan model pembelajaran berbasis masalah. Hal ini akan mempermudah siswa dalam proses penyelidikan dan pengumpulan informasi yang berkaitan dengan masalah yang diberikan. Siswa akan bekerja sama dengan kelompoknya untuk mengumpulkan informasi, melakukan penyelidikan, dan bertukar pendapat mengenai masalah yang diberikan. Informasi yang dikumpulkan kemudian didiskusikan dengan teman kelompoknya sehingga siswa yang mempunyai kemampuan lebih dapat membantu temannya yang mempunyai kemampuan kurang sehingga setiap siswa mampu memecahkan masalah yang diberikan.

Model pembelajaran pembelajaran berbasis masalah merupakan model pembelajaran yang berpusat pada siswa. Pada prosesnya guru hanya berperan sebagai fasilitator dan pembimbing siswa, sehingga siswa dapat mencari tahu pengetahuan yang akan dipelajari. Siswa berperan aktif dalam proses pembelajaran, sehingga komunikasi yang terjalin adalah komunikasi yang multi arah. Pelaksanaan pembelajaran pada model pembelajaran berbasis masalahadalah menuntut siswa untuk menemukan atau menggali pengetahuannya sendiri. Siswa diberikan kesempatan untuk menemukan maupun menyajikan konsep-konsep dalam pembelajaran, guru berperan sebagai fasilitator yang membantu siswa mengkotruksikan pengetahuannya.

Pembelajaran melalui model pembelajaran berbasis masalah adalah suatu pembelajaran yang melibatkan siswa dalam proses kegiatan mental melalui tukar pendapat, berdiskusi, membaca sendiri dan mencoba sendiri. Mengaplikasikan model pembelajaran berbasis masalah dalam pembelajaran matematika secara tepat dan berulangulang maka dapat meningkatkan kemampuan personal siswa yang bersangkutan dan menjadikan siswa lebih percaya diri untuk mengungkapkan gagasannya. Tujuan pelaksanaan pembelajaran ini dapat menanamkan pengetahuan yang diperoleh siswa secara bertahan lama, mudah diingat dan mudah diterapkan pada situasi baru. Hal tersebut terjadi karena pengetahuan dan konsep yang didapat siswa ditemukan oleh siswa itu sendiri.

Pada dasarnya model pembelajaran berbasis masalah ingin mengubah kondisi dan proses pembelajaran yang terjadi saat ini yaitu dari pasif menjadi aktif dan kreatif. Mengubah pembelajaran yang teacher oriented ke student oriented. Runtutan pembelajaran tersebut dapat meningkatkan penalaran, analisis dan keterampilan dalam memecahkan masalah, meningkatkan kreatifitas siswa untuk terus belajar dan tidak hanya menerima saja, sehingga siswa dapat terampil dalam menemukan konsep atau memecahkan masalah. Siswa merasa senang ketika mampu menemukan materi maupun jawaban yang sedang dipelajarinya secara sendiri. Penggunaan yang secara tepat ini dapat meningkatkan hasil belajar yang baik pada siswa khususnya dalam pembelajaran matematika.

Hasil temuan dalam penelitian ini sejalan dengan penelitian yang dilakukan 
oleh Hajric (2015) dengan judul "The effects of problem-based learning on students' achievements in primary school chemistry", menunjukkan bahwa the findings of this study showed the benefits of problem-based learning as teaching method in primary school chemistry. The main hypothesis, that a problem-based learning is more efficient than conventional teaching methods in chemistry (based on teacher-centered approach) is confirmed. Also, we have encountered some difficulties in using this method, primarily due to its rare application in primary school teaching generally. We believe that if teachers applied this method more extensively, these problems would be minimized, while both students and their teachers would benefit from it.

Dari uraian dan temuan yg relevan tersebut, jelas terlihat bahwa hasil belajar siswa yang megikuti model pembelajaran berbasis masalah lebih baik daripada hasil belajar siswa yang diajar menggunakan model pembelajaran konvensional.

\section{Pengaruh Interaksi Antara Model Pembelajaran Berbasis Masalah dengan Kemampuan Berpikir Kritis Terhadap Hasil Belajar Matematika Siswa Kelas IV SD Gugus I Kecamatan Buleleng \\ Analisis data telah membuktikan} bahwa terdapat interaksi antara model pembelajaran berbasis masalah dengan kemampuan berpikir kritis terhadap hasil belajar matematika Siswa Kelas IV SD Gugus I Kecamatan Buleleng dibandingkan dengan siswa yang mengikuti model pembelajaran konvensional. Hal ini ditunjukkan dengan nilai rata-rata hasil belajar siswa dengan kemampuan berpikir kritis tinggi yang mengikuti pembelajaran dengan model pembelajaran berbasis masalah dengan skor rata-rata 25,95 lebih tinggi daripada hasil belajar siswa dengan kemampuan berpikir kritis rendah yang mengikuti pembelajaran dengan model pembelajaran berbasis masalah dengan skor rata-rata 20,13 . Jadi terdapat bahwa pengaruh interaksi antara model pembelajaran berbasis masalah dengan kemampuan berpikir kritis terhadap hasil belajar matematika siswa kelas IV SD Gugus I Kecamatan Buleleng.

Model pembelajaran berbasis masalah adalah salah satu model pembelajaran inovatif yang cocok diterapkan dalam proses pembelajaran. Model pembelajaran ini memberikan permasalahan dalam konteks dunia nyata. Berdasarkan masalah tersebut, siswa ditugaskan untuk menyelesaikan permasalahan yang telah diberikan. Dengan menggunakam model pembelajaran berbasis masalah, siswa akan mampu membangun pengetahuannya sendiri melalui proses pemecahan masalah yang telah dilakukannya, sehingga siswa akan lebih mudah memahami materi pembelajaran yang diberikan dan hal ini akan berdampak pada hasil belajarnya yang tinggi. Pembelajaran berbasis masalah adalah suatu model pembelajaran yang melibatkan siswa untuk memecahkan suatu masalah melalui beberapa tahapan sehingga siswa dapat mempelajari pengetahuan yang berhubungan dengan masalah tersebut dan sekaligus memiliki keterampilan untuk memecahkan masalah sehingga akan berdampak pada peningkatan kemampuan berpikir kritis siswa. Masalah yang dijadikan fokus pembelajaran dapat diselesaikan siswa melalui kerja kelompok sehingga dapat memberi pengalaman-pengalaman belajar yang beragam pada siswa seperti kerjasama dan interaksi dalam kelompok.

Model pembelajaran pembelajaran berbasis masalah mampu memfasilitasi siswa untuk aktif dalam menemukan dan mengembangkan fakta, konsep, prinsip ilmu atau pengetahuan sehingga dapat meningkatkan hasil belajar siswa. Pengetahuan yang diperoleh kemudian difasilitasi sehingga membentuk cara berpikir yang dimiliki siswa dengan cara 
memilih, mengidentifikasi, mengkaji dan mengembangkan pengetahuannya ke arah yang lebih sempurna. Proses pembelajaran yang terjadi, siswa diberikan kesempatan untuk menjadi seorang problem solver, seorang scientis, historinatau ahli matematika. Pada model pembelajaran berbasis masalah bahan ajar tidak disajikan dalam bentuk akhir, siswa dituntut untuk melakukan berbagai kegiatan menghimpun informasi, membandingkan, mengkategorikan, menganalisis, mengintegrasikan, mereorganisasikan bahan serta membuat kesimpulan-kesimpulan. Hal tersebut mampu membangun dan meningkatkan kemampuan berpikir kritis yang dimiliki siswa tersebut. Siswa yang memiliki kemampuan berpikir kritis tinggi akan memiliki kelancaran dalam berpikir dan memiliki motivasi yang besar serta ketekunan dalam mempelajari suatu konsep serta selalu mencoba melakukan penyelidikan dan menguji kebenaran suatu konsep yang dipelajarinya.

Penggunaan model pembelajaran berbasis masalah mampu mengkonstruksikan pengetahuan yang dimiliki siswa dan melatih siswa memiliki rasa ingin tahu setiap ditemukan masalah, membangun kemampuan dalam menemukan jawaban maupun materi yang sedang dipelajari, meningkatkan kemampuan siswa dalam menganalisis data dan jujur terhadap data yang diperoleh, memupuk sikap tekun, disiplin, serta kerjasama dalam memperoleh jawaban dalam suatu proses penyelidikan, dengan demikian siswa dapat membangun kemampuan berpikir kritisnya. Keterampilan dalam proses pembelajaran juga diperlukan agar hasil pembelajaran berjalan sesuai dengan yang direncanakan. Keterampilan yang dapat dikembangkan dalam kemampuan berpikir kritis yaitu analisis yang meliputi langkahlangkah logis dalam berpikir, sintesis yaitu menggabungkan suatu pemikiran dan memunculkan gagasan baru, memahami dalam memecahkan masalah, menyimpulkan akal pikiran dan mengevaluasi terhadap hasil yang sudah dibuat.

Model pembelajaran berbasis masalah sangat efektif digunakan dalam meningkatkan kemampuan berpikir kritis, sedangkanpada pembelajaran konvensional kurang dapat meningkatkan secara optimal kemampuan berpikir kritis siswa karena pembelajaran bersifat pasif dan kurang berinteraksi. Hal tersebut dapat mempengaruhi hasil belajar dan pengembangan kemampuan berpikir kritis. Kemampuan berpikir kritis matematika juga menjadi faktor dalam menentukan hasil belajar matematika. Siswa yang memiliki keterampilan berpikir kritis akan, (1) mampu merumuskan masalah, yaitu mampu mencari pertanyaan, (2) mampu memberikan argumen, yaitu memberi alasan yang sesuai dari setiap pertanyaan, (3) mampu melakukan deduksi yaitu kecakapan untuk menentukan kesimpulan dari hal yang bersifat umum ke hal yang bersifat khusus, (4) mampu melakukan induksi yaitu kecakapan untuk menentukan kesimpulan dari hal yang bersifat khusus ke hal yang bersifat umum, (5) mampu melakukan evaluasi yaitu kemampuan untuk menilai suatu argumen, (6) mampu memutuskan dan melaksanakan, yaitu kemampuan untuk memutuskan suatu solusi dan melaksanakan solusi tersebut, sehingga siswa yang memiliki kemampuan berpikir kritis akan dapat bertindak secara normatif, siap bernalar tentang sesuatu yang dilihat, dengar atau pikirkan serta mampu memecahkan pemasalahan yang dihadapinya sehingga dapat berdampak positif dalam peningkatan hasil belajar siswa.

Hasil temuan dalam penelitian ini sejalan dengan hasil penelitian yang dilakukan oleh Tresna D,P,N (2016) dengan judul "Pengaruh Model Pembelajaran Berbasis Masalah dan Keterampilan Berpikir Kreatif Terhadap Hasil Belajar Matematika Siswa Kelas IV SD Gugus II Sukawati”. Hasil penelitian ini 
menyatakan bahwa terdapat perbedaan hasil belajar pada siswa yang mengikuti model pembelajaran berbasis masalah dengan siswa yang mengikuti pembelajaran konvensional. Hasil belajar siswa yang mengikuti pembelajaran dengan model pembelajaran berbasis masalah lebih tinggi dari siswa yang mengikuti pembelajaran konvensional. Relevansinya dengan penelitian ini adalah sama-sama menggunakan model Problem Based Leaning dan hasil belajar matematika.

Berdasarkan pernyataan di atas, dapat dikatakan bahwa terdapat pengaruh interaksi antara model pembelajaran berbasis masalah dengan kemampuan berpikir kritis terhadap hasil belajar matematika.

\section{Perbedaan Hasil Belajar Matematika Antara Siswa yang Mengikuti Model Pembelajaran Berbasis Masalah dengan Siswa yang Mengikuti Model Pembelajaran Konvensional pada Siswa Kelas IV SD Gugus I Kecamatan Buleleng Pada Siswa yang Memiliki Kemampuan Berpikir Kritis Tinggi}

Berdasarkan analisis data ternyata terdapat perbedaan hasil belajar matematika antara siswa yang mengikuti model pembelajaran berbasis masalah dengan siswa yang mengikuti model pembelajaran konvensional pada siswa kelas IV SD Gugus I Kecamatan Buleleng pada siswa yang memiliki kemampuan berpikir kritis tinggi. Rata-rata skor hasil belajar matematika siswa yang memiliki kemampuan berpikir kritis tinggi yang mengikuti model pembelajaran berbasis masalah adalah sebesar 25,96. Sedangkan rata-rata skor hasil belajar matematika siswa yang memiliki kemampuan berpikir kritis tinggi yang mengikuti pembelajaran dengan model konvensional adalah sebesar 19. Sedangkan rata-rata jumlah kuadrat dalam adalah sebesar 11,713.
Penghitungan dengan hasil uji tukey menunjukkan nilai $Q$ hitung sebesar 17,51. Model pembelajaran berbasis masalah menjadikan guru sebagai fasilitator dan motivator, sehingga siswa yang aktif mengkonstruksi pengetahuannya. Pada awal pembelajaran siswa akan diberikan masalah dan ditugaskan untuk menyelesaikan masalah bersama teman kelompoknya dengan melakukan diskusi sehingga memberikan kesempatan pada siswa untuk menggunakan beragam ide dan kemampuannya. Dengan melakukan hal ini, siswa akan lebih mudah untuk memahami materi pelajaran, pembelajaran akan menjadi bermakna bagi siswa sehingga materi yang dipelajari tidak akan mudah untuk dilupakan. Keberhasilan siswa dalam belajar matematika dapat dilihat dari hasil belajar siswa. Hasil belajar merupakan perubahan tingkah laku akibat belajar. Perubahan tingkah laku disebabkan karena mencapai penguasaan atas sejumlah bahan yang diberikan dalam proses pembelajaran.

$$
\text { Berpikir kritis merupakan }
$$

kemampuan menelaah atau menganalisis suatu sumber, mengidentifikasi sumber yang relevan dan yang tidak relevan, mengidentifikasi dan mengevaluasi asumsi, menerapkan berbagai strategi untuk membuat keputusan yang sesuai dengan standar penilaian. Model pembelajaran berbasis masalah dapat berfungsi melatih siswa dalam membangun pengetahuannya sendiri. Tinggi atau rendahnya hasil belajar siswa dapat dilihat dari kemampuan pemahaman konsep dan kemampuan siswa dalam memecahkan masalah. Siswa yang memiliki kemampuan berpikir kritis yang tinggi akan sangat membantu dalam menentukan informasi yang penting didapatkan, diubah, ditransformasi, dan dipertahankan, sehingga secara tidak langsung, ini akan membantu siswa dalam memecahkan masalah matematika yang dihadapi. Ketika siswa mampu memecahkan masalah matematika yang 
dihadapi, maka itu berarti siswa sudah memahami konsep matematika sepenuhnya.

Dari uraian di atas tergambar jelas bahwa terdapat perbedaan hasil belajar matematika antara siswa yang mengikuti model pembelajaran berbasis masalah dengan siswa yang mengikuti model pembelajaran konvensional pada siswa kelas IV SD Gugus I Kecamatan Buleleng pada siswa yang memiliki kemampuan berpikir kritis tinggi.

\section{Perbedaan Hasil Belajar Matematika antara Siswa yang Mengikuti Model Pembelajaran Berbasis Masalah dengan Siswa yang Mengikuti Model Pembelajaran Konvensional pada Siswa Kelas IV SD Gugus I Kecamatan Buleleng pada Siswa yang Memiliki Kemampuan Berpikir Kritis Rendah}

Berdasarkan analisis data ternyata terdapat perbedaan hasil belajar matematika antara siswa yang mengikuti model pembelajaran berbasis masalah dengan siswa yang mengikuti model pembelajaran konvensional pada siswa kelas IV SD Gugus I Kecamatan Buleleng pada siswa yang memiliki kemampuan berpikir kritis rendah. Rata-rata skor hasil belajar matematika siswa yang memiliki kemampuan berpikir kritis rendah yang mengikuti model pembelajaran berbasis masalah adalah sebesar 20,13. Sedangkan rata-rata skor hasil belajar matematika siswa yang memiliki kemampuan berpikir kritis rendah yang mengikuti pembelajaran dengan model konvensional adalah sebesar 22,65. Sedangkan rata-rata jumlah kuadrat dalam adalah sebesar 11,713. Penghitungan dengan hasil uji tukey menunjukkan nilai $Q$ hitung sebesar 6,90.

Siswa yang memiliki kemampuan berpikir kritis rendah pada umumnya memiliki cara berpikir yang kurang teratur dalam mengerjakan sesuatu maupun dalam memecahkan masalah matematika. Jika hal tersebut diakomodasi dengan baik dalam pembelajaran di kelas, maka siswa dengan kemampuan berpikir kritis tinggi akan cenderung lebih cepat dan lebih mudah dalam menyelesaikan masalah matematika yang berdampak pada tingginya hasil belajar pesesrta didik. Namun apabila guru bisa menerapkan model pembelajaran konvensional maka siswa dengan kemampuan berpikir kritis rendah bisa memecahkan masalah yang diberikan oleh guru dengan baik dan mengakibatkan tingginya hasil belajar siswa. Hal ini disebabkan oleh anak yang memiliki kemampuan berpikir kritis rendah lebih terbiasa menggunakan model pembelajaran konvensional dibadingkan dengan model pembelajaran pembelajaran berbasis masalah. Keberhasilan siswa dalam belajar matematika dapat dilihat dari hasil belajar siswa. Hasil belajar merupakan kemampuan-kemampuan yang dimiliki siswa sebagai akibat perbuatan belajar.

Tinggi atau rendahnya hasil belajar siswa dapat dilihat dari kemampuan pemahaman konsep dan kemampuan siswa memecahkan masalah. Dalam memecahkan masalah matematika, setiap siswa tentunya memiliki kemampuan yang berbeda-beda. Tidak hanya pengakomodasian cara belajar yang bisa mempengaruhi kemampuan pemecahan masalah siswa, kemampuan numerik pun sangat mempengaruhi hasil belajar. Berdasarkan pernyataan di atas, bahwa hasil belajar matematika siswa yang memiliki kemampuan berpikir kritis rendah yang belajar melalui penerapan model pembelajaran berbasis masalah lebih rendah dibandingkan siswa yang belajar melalui pembelajaran konvensional.

Secara keseluruhan hasil penelitian ini, dapat disimpulkan bahwa model pembelajaran berbasis masalah sangat efektif diterapkan untuk meningkatkan kemampuan berpikir kritis dan hasil belajar matematika siswa.

\section{PENUTUP}


Berdasarkan empat temuan dari hasil pengujian hipotesis seperti disajikan pada bab IV, maka dalam penelitian ini diperoleh empat simpulan sebagai berikut.

1. Temuan penelitian menunjukkan bahwa terdapat perbedaan hasil belajar matematika antara siswa yang mengikuti model pembelajaran berbasis masalah dengan siswa yang mengikuti model pembelajaran konvensional pada siswa kelas IV SD Gugus I Kecamatan Buleleng.

2. Temuan penelitian menunjukkan pengaruh interaksi antara model pembelajaran berbasis masalah dengan kemampuan berpikir kritis terhadap hasil belajar matematika siswa kelas IV SD Gugus I Kecamatan Buleleng.

3. Temuan penelitian menunjukkan untuk siswa yang memiliki kemampuan berpikir kritis tinggi, ada perbedaan hasil belajar matematika antara siswa yang mengikuti model pembelajaran berbasis masalah dengan siswa yang mengikuti model pembelajaran konvensional pada siswa kelas IV SD Gugus I Kecamatan Buleleng.

4. Temuan penelitian menunjukkan untuk siswa yang memiliki kemampuan berpikir kritis rendah, ada perbedaan hasil belajar matematika antara siswa yang mengikuti model pembelajaran berbasis masalah dengan siswa yang mengikuti model pembelajaran konvensional pada siswa kelas IV SD Gugus I Kecamatan Buleleng.

\section{DAFTAR RUJUKAN}

Candiasa, I Made. 2010. Statistik Univariat dan Bivariat disertai Aplikasi SPSS. Singaraja: Universitas Pendidikan Ganesha.

Depdiknas. 2006. Kurikulum Tingkat Satuan Pendidikan (KTSP). Jakarta: Depdiknas.

Hajric, Zejnilagic, A, Sabeta \& I, Nuic. 2015. The effects of problem-based learning on student's achievements in primary school chemistry.Journal of Education and Practice Vol 6 (2015). Diakses pada 20 Juni 2018.

Tresna Dewi, Pande Nyoman. 2016. Pengaruh Model Pembelajaran Berbasis Masalah dan Keterampilan Berpikir Kreatif Terhadap Hasil Belajar Matematika Siswa Kelas IV $S D$ Gugus II Sukawati. E-Journal Program Pascasarjana Universitas Pendidikan Ganesha.Vol 6 (2016). Diakses 13 Juni 2018.

Tukiran. 2014. Model-Model Pembelajaran Inovatif dan Efektif. Bandung: Alfabeta

Undang-undang Republik Indonesia Nomor 20 Tahun 2003 Tentang Sistem Pendidikan Nasional. Jakarta: Depdiknas.

Wijayanti. 2015. Peningkatan Kemampuan Berpikir Kritis Siswa Melalui Penerapan Model Pembelajaran Inkuiri Terbimbing Pada Konsep Sel Dan Jaringan. Jurnal UIN. Vol 3 No. 1. 2015. Tersedia pada http://journal.uin-

alauddin.ac.id/index .php/biotek/articl e/view/1924.(diakses pada tanggal 3 Desember 2018). 